\title{
Assessment of Students' Knowledge and Attitudes Related to Physiological Changes of Elderly People in El-Azhar Univeristy at Assuit City, Egypt.
}

\author{
Fatma Elzhraa Ahmed Hassan ${ }^{1}$, Nermeen Mahmoud Abd El-Aziz ${ }^{2}$, Saieda Abd-El Hameed Abd-ELaziz ${ }^{3}$. \\ 1- Nursing Specialist of Nursing Instantiation, El-Azhar University, Assuit City, Egypt. \\ 2- Assistant Professor of Gerontological Nursing, Faculty of Nursing, Assuit University, Egypt. \\ 3- Lecturer of Gerontological Nursing, Faculty of Nursing, Assuit University, Egypt.
}

\begin{abstract}
The study aimed to assess the students' knowledge and attitudes related to physiological changes of elderly people in El-Azhar University at Assuit city, Egypt. Design: A descriptive research design was utilized. Setting: This study conducted in two faculties (Education and Shariaa and low) at El-azahr University. The total sample size was 363 female students who were selected by random sample from two faculties in El-Azhar University at Assuit City. Three tools were used, tool 1: Students' socio-demographic characteristic and education background questionnaire, tool II: facts on aging quiz 2 (FAQZ) and tool III: attitude toward old people scale (ATOP). Results: $44.6 \%$ of students participants had fair knowledge, $70.2 \%$ of students participants had negative attitude, also there was a significant positive correlation between knowledge score and attitude score $(r=0.114 \& \mathrm{p}=0.029)$, and there was a significant positive correlation between their ages and knowledge score $(r=0.134 \& p=0.011)$. Conclusion Majority of students had a fair score of knowledge related to physiological changes which occur to the elderly people however; the majority of them had a negative attitude toward elderly people. Recommendation: an educational program to raise the level of knowledge and attitude related to physiological changes of elderly people is needed.
\end{abstract}

\section{Keywords: Physiological Changes, Elderly, Knowledge \& Attitude.}

\section{Introduction}

The term 'Elderly' is applied to those individuals belonging to age 60 years and above, who represent the fastest-growing segment of populations throughout the world (Dobriansky, 2015). According to the World Health Organization (2018), ageing is a course of biological reality which starts at conception and ends with death. In most of the developed countries, the age of 60 is considered equivalent to retirement age and it is said to be the beginning of old age (McNicoll, 2018).

Aging is an inevitable and extremely complex, multifactorial process, is characterized by the progressive degeneration of organ systems and tissues. It is largely determined by genetics and influenced by a wide range of environmental factors, such as diet, exercise, exposure to microorganisms, pollutants, and ionizing radiation (Knight \& Nigam, 2018).

Aging begins as soon as adulthood is reached and as much a part of human life as infancy, childhood, and adolescence. Gerontology (the study of aging) is concerned primarily with the changes that occur between the attainment of maturity and the death of the individual (National Institute on Aging, 2019).

Aging is inevitable, and as life expectancy increases it becomes more important to understand physiological mechanisms associated with the normal aging process so that quality of life can be sustained, the physiological changes associated with normal aging are mirrored during periods of immobility, such as prolonged hospital bed rest, or after a fractured limb or a fall (Sieck, 2018).

The person aged 65 years or older person represented $6.7 \%$ of the total population in Egypt (Central agency for public mobilization statistic, 2019). Which indicated that the total population of Egyptian people were 94.8 million, elderly people (60 years and more) represents $7 \%$ of the total population in Egypt and expected to reach $12 \%$ by 2030 .

According to the World Health Organization (2019) between 2000 and 2050, the proportion of the world over 60 years will double from $11 \%$ to $22 \%$. The absolute number of persons aged 60 years and over is expected to increase from 605 million to 2 billion over the same period.

Aging affects all physiological processes. Subtle irreversible changes in the function of most organs can be shown to occur by the third and fourth decades of life, with progressive deterioration (Brandfonbrener et al., 2018).

With the increasing aged population, there is an increase of developing health problems which consequently increase the demand for health care resources. Globally, the number of aging people (60 years and over) is expected to increase from 600 million to 2 billion between 2000 and 2050 (Worled Health Organization, 2018). 


\section{Significance of the study}

Egypt's elderly population had reached 6.5 million (3.5 million males and 3 million females) (Central Agency for public Mobilization \& statistics, 2019). It has been observed that the students haven't insufficient knowledge about aging (Aubrey \& Grey, 2017). Hope's study suggested that a lower knowledge level of gerontic care may indicate a more negative attitude towards older people (Hope, 2016). The proportion of older people has increased worldwide and so the health problems related to ageing, such as cardiovascular disease (Cabeza, 2019). So this study was suggested to assess the students' knowledge and attitude related to physiological changes of elderly people. The elderly need nursing care which should be provided by a nurse who is knowledgeable, skilled, vigilant, sensitive, proactive, respectful and positively motivated about caring for the older persons (Purty et al., 2018).

\section{Study aim}

To assess the students' knowledge and attitudes related to physiological changes of Elderly People in El-Azhar University at Assuit City, Egypt.

\section{Research Question}

What are the student's knowledge and attitudes related to physiological changes of elderly people in El-Azhar University at Assuit City, Egypt?

\section{Subjects \& Methods}

Research Design: Descriptive cross-sectional research design was used in this study.

Setting: The study was carried out in two faculties in El-Azhar University at Assiut City (education and Shariaa and low).

Sample: Random sample was used and chosen from both faculty of education and Shariaa and low), which were chosen randomly from $\mathbf{1 1}$ faculties. The total sample was (336) female students. By using soft EPI /Info, version 3with confidence level 95\%.the estimated sample size found to be 330 students, to compensate the drop out, $10 \%$ add to the sample size; the final sample size will be 365 students. The study starting from September (2018) to November (2019) through three days a week. The average number, which interviewed was 3-5 students per day and the average time taken for completing each sheet was around 25-30 minutes.

Study tools: data collected using 3tools

Tool I: consisted of 3 parts

The $1^{\text {st }}$ part was included socio-demographic characteristic of the study sample such as name, age, academic year level ...etc.
The $2^{\text {nd }}$ part included questions related to previous knowledge of aging and experiences of caring such experience living with elderly, interest in elderly care/issues, communication with elderly, previous knowledge of aging and source of this knowledge.

The $3^{\text {rd }}$ part included questions related to physiological changes of the elderly. Such changes in special senses, changes in the musculoskeletal system, memory, and nervous system ....etc.

Tool II: Facts on aging quiz 2 (FAQZ) the FAQ2 was developed by Palmore, (2000):

This tool was used in different studies to test student's knowledge about physiological changes of elderly people it consisted of (25) true-false statements which measure knowledge related to basic physical, psychological and social facts on aging.

Scoring system: The knowledge score for each participant is the sum of the correct answer, with possible score ranged from (0 to 25$)$ and expressed as mean scores. The higher total knowledge score indicates greater knowledge of aging. Less than 50\% of the correct answer was poor knowledge of $50 \%$ to $70 \%$ was fair knowledge and more than $70 \%$ good knowledge.

Tool III: Attitude toward old people scale (ATOP) by Kogan, (1961).

This tool was translated and modified by Zakari, (2005) to assess student's attitude toward elderly people and consists of 17 statement each with positive and negative element participant responses are arranged on a 6 point likert-like scale format. The point descriptors ranged from strongly disagree (1), slightly disagree (2), disagree (3), agree (4), slightly agree (5) and strongly agree (6).

Scoring system: The higher scores indicated positive student attitude toward the elderly people. Less than $60 \%$ was a negative attitude and more than $60 \%$ was positive attitude.

\section{Validity \& Reliability of the tools}

Tools were tested for their content validity by a group of five experts in community and gerontological health nursing. The required modifications were done. Test of the study tools' reliability was done by to alpha Cronbach test $(\mathrm{r}=0.8)$.

\section{Methods}

\section{Administrative stage}

It includes the following activities: the actual number of students was obtained from the administration of El-Azhar University. An official approval letter was obtained from the dean of faculty of nursing at Assuit University to the director of El-Azhar nursing institution than to the dean of each faculty (education and Shariaa) to obtain the permission for carrying out this study. Approval was obtained from the dean of each faculty to meet the students and collect the 
necessary data after explaining the purpose and nature of the study.

\section{Pilot study}

A pilot study was carried out of $10 \%$ of the studied students, which excluded from the study subject. Then some significant modifications were done to avoid the ambiguous of the questionnaire.

\section{Ethical Consideration}

Nursing faculty ethical committee approved the research proposal. There was no risk for study subject during application of the research. Clinical research ethical principles were followed in this study. The right of refusing to participate in every elderly participant was assured and withdraw at any time from the study without any rationale.

\section{Data collection}

was conducted during the period from September (2018) to November (2019) through three days a week. The average number of the interviewed was 35 students per day and the average time taken for completing each sheet was around 25-30 minutes. The researcher interviewed the students according to their circumstances in order to obtain the necessary information. The aim of the study was briefly explained through direct communication with each student.

\section{Statistical analysis}

Data entry and data analysis were done using SPSS version 22 (Statistical Package for Social Science). Data was presented as number, percentage, mean and standard deviation. Chi-square test was used to compare qualitative variables. Pearson correlation was done to measure the correlation between quantitative variables. $\mathrm{P}$-value considered statistically significant when $\mathrm{P}<0.05$.

\section{Results}

Table (1): Distribution of studied sample according to their socio-demographic data in El-Azhar University at Assiut city, 2018.

\begin{tabular}{|c|c|c|}
\hline Variables & N. (363) & $\%$ \\
\hline \multicolumn{3}{|l|}{ Age: (in years) } \\
\hline$<20$ & 86 & 23.7 \\
\hline 20 & 110 & 30.3 \\
\hline$>20$ & 167 & 46.0 \\
\hline Mean \pm SD (Range) & \multicolumn{2}{|c|}{$20.48 \pm 1.32(18.0-24.0)$} \\
\hline \multicolumn{3}{|l|}{ Faculty: } \\
\hline Education & 182 & 50.1 \\
\hline Shariaa and Law & 181 & 49.9 \\
\hline \multicolumn{3}{|l|}{ Academic year: } \\
\hline First & 65 & 17.9 \\
\hline Second & 113 & 31.1 \\
\hline Third & 110 & 30.3 \\
\hline Fourth & 42 & 11.6 \\
\hline Fifth & 33 & 9.1 \\
\hline \multicolumn{3}{|l|}{ Marital status: } \\
\hline Single & 336 & 92.6 \\
\hline Married & 27 & 7.4 \\
\hline \multicolumn{3}{|l|}{ Number of family member: } \\
\hline$\leq 5$ & 120 & 33.1 \\
\hline $6-7$ & 162 & 44.6 \\
\hline$>7$ & 81 & 22.3 \\
\hline Mean \pm SD (Range) & \multicolumn{2}{|c|}{$6.33 \pm 1.69(2-15)$} \\
\hline \multicolumn{3}{|l|}{ Residence: } \\
\hline Rural & 142 & 39.1 \\
\hline Urban & 221 & 60.9 \\
\hline \multicolumn{3}{|l|}{ Age of elderly person at home: } \\
\hline $60-69$ years & 197 & 54.3 \\
\hline $70-79$ years & 138 & 38.0 \\
\hline$\geq 80$ years & 28 & 7.7 \\
\hline
\end{tabular}




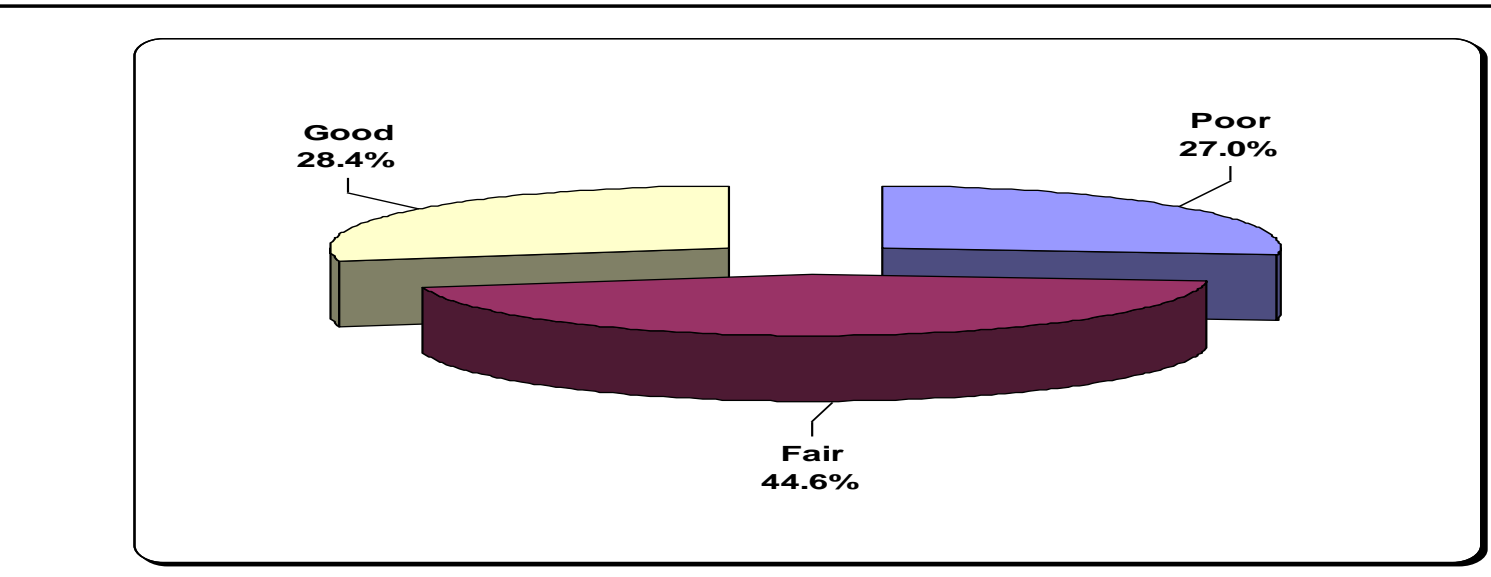

Pearson correlation

Figure (1): Distribution of total studied students' knowledge level about physiological changes of elderly people.

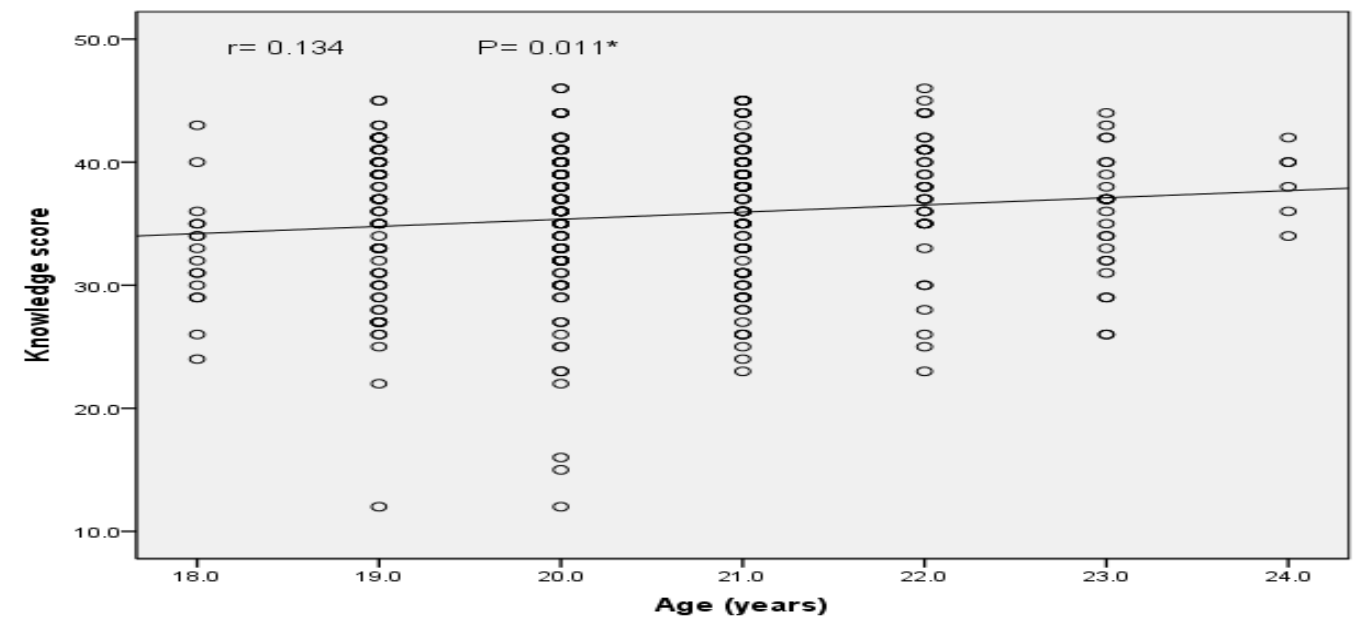

Pearson correlation

Figure (2): Correlation between students' ages and their knowledge scors

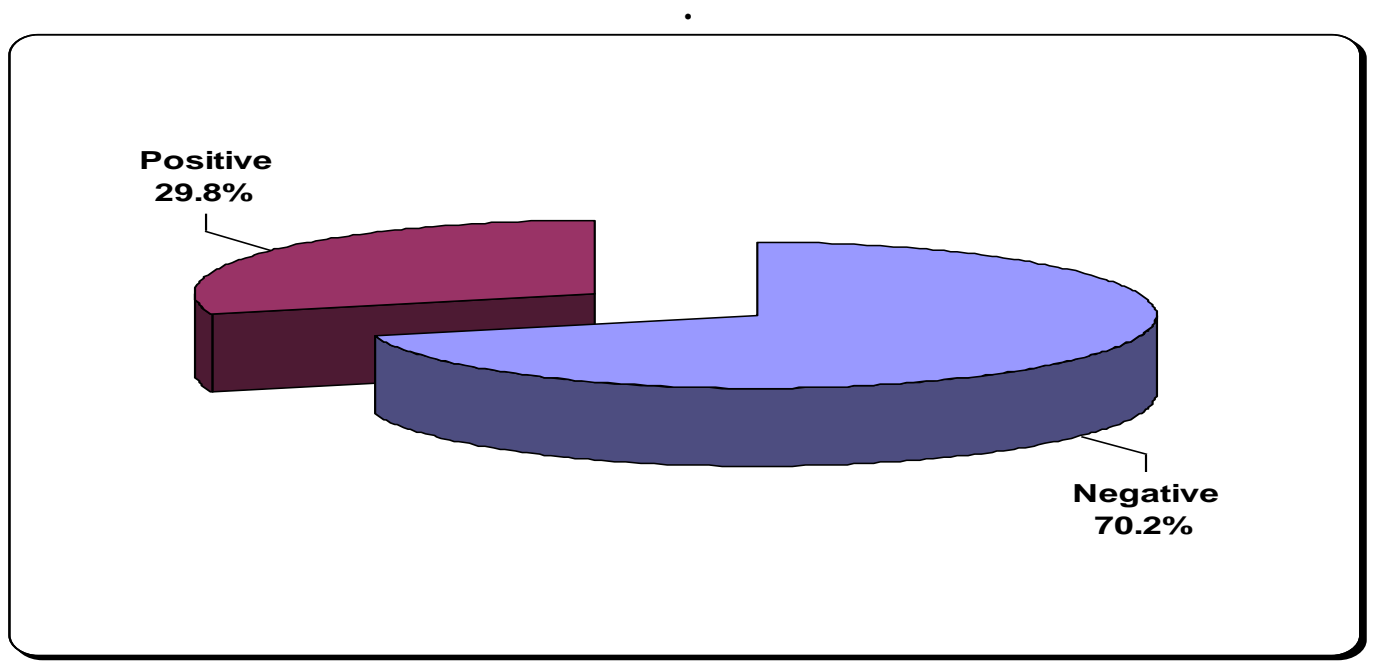

Pearson correlation

Figure (3): Distribution of the total studied students' attitude level regarding elderly persons. 
Table (2): Relationship between attitude level toward elderly people and socio-demographic.

\begin{tabular}{|c|c|c|c|c|c|}
\hline \multirow{3}{*}{ Socio demographic data } & \multicolumn{4}{|c|}{ Attitude level } & \multirow{3}{*}{ P-value } \\
\hline & \multicolumn{2}{|c|}{$\begin{array}{l}\text { Negative } \\
(n=255)\end{array}$} & \multicolumn{2}{|c|}{$\begin{array}{l}\text { Positive } \\
(n=108)\end{array}$} & \\
\hline & $\mathbf{N}$ & $\%$ & $\mathbf{N}$. & $\%$ & \\
\hline \multicolumn{5}{|l|}{ Faculty } & \multirow{3}{*}{0.470} \\
\hline Education & 131 & 72.0 & 51 & 28.0 & \\
\hline Shariaa and Law & 124 & 68.5 & 57 & 31.5 & \\
\hline \multicolumn{5}{|l|}{ Academic year } & \multirow{6}{*}{0.284} \\
\hline First & 39 & 60.0 & 26 & 40.0 & \\
\hline Second & 84 & 74.3 & 29 & 25.7 & \\
\hline Third & 79 & 71.8 & 31 & 28.2 & \\
\hline Fourth & 28 & 66.7 & 14 & 33.3 & \\
\hline Fifth & 25 & 75.8 & 8 & 24.2 & \\
\hline \multicolumn{5}{|l|}{ Age: (in years) } & \multirow{4}{*}{0.278} \\
\hline$<20$ & 56 & 65.1 & 30 & 34.9 & \\
\hline 20 & 83 & 75.5 & 27 & 24.5 & \\
\hline$>20$ & 116 & 69.5 & 51 & 30.5 & \\
\hline \multicolumn{5}{|l|}{ Marital status } & \multirow{3}{*}{0.374} \\
\hline Single & 234 & 69.6 & 102 & 30.4 & \\
\hline Married & 21 & 77.8 & 6 & 22.2 & \\
\hline \multicolumn{5}{|l|}{ Number of family member } & \multirow{4}{*}{0.407} \\
\hline$\leq 5$ & 89 & 74.2 & 31 & 25.8 & \\
\hline $6-7$ & 113 & 69.8 & 49 & 30.2 & \\
\hline$>7$ & 53 & 65.4 & 28 & 34.6 & \\
\hline \multicolumn{5}{|l|}{ Residence: } & \multirow{3}{*}{0.377} \\
\hline Rural & 96 & 67.6 & 46 & 32.4 & \\
\hline Urban & 159 & 71.9 & 62 & 28.1 & \\
\hline \multicolumn{5}{|l|}{$\begin{array}{l}\text { Do you have an elderly person at } \\
\text { home? }\end{array}$} & \multirow{3}{*}{0.207} \\
\hline $60-69$ years & 177 & 89.8 & 20 & 10.2 & \\
\hline $70-79$ years & 67 & 48.6 & 71 & 51.4 & \\
\hline$\geq 80$ years & 11 & 39.3 & 17 & 60.7 & \\
\hline
\end{tabular}

Chi square test

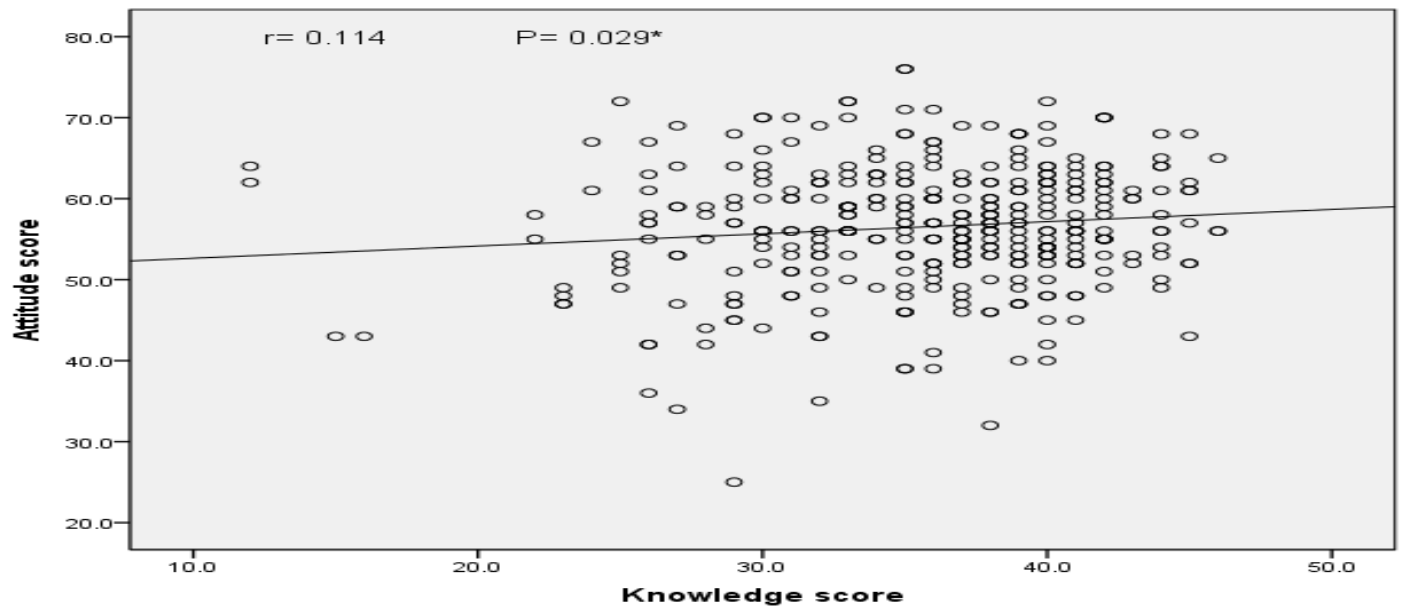

Pearson correlation

Figure (4): Correlation between students' total knowledge and attitude scores toward elderly persons. 
Table (1): Showed that, $46 \%$ of the studied students' age group was more than 20 years old with mean $(20.48 \pm 1.32), 50.1 \%$ of them were from faculty of education, $31.1 \%$ were in the second academic year. The majority $92.6 \%$ of them were single, $44 \%$ of them had from 6 to 7 family members, $60 \%$ come from urban areas, in addition, 54\% had an elderly person with age 60-79 years at their homes.

Figure (1): Cleared that a distribution of total studied students' knowledge level about physiological changes of elderly people, illustrated that the majority of the studied students $44.6 \%$ had fair knowledge level.

Figure (2): Showed that there was a significant positive correlation between the students' ages and their knowledge scores $(r=0.134 \& \mathrm{p}=0.011)$.

Figure (3): Illustrated that majority $(70.2 \%)$ of the studied students had a negative attitude toward elderly people.

Table (2): Presented that there was no statistically significant relationship between studied students' attitude level toward elderly people and their sociodemographic data.

Figure (4): Reveals that there was a significant positive correlation between studied students' knowledge and attitude scores $(r=0.114 \& \mathrm{p}=0.029)$ regarding the elderly persons.

\section{Discussion}

Aging is a physiologically occurring part of the lifecycle. This natural process includes physical, social, and psychological changes. These changes should be accepted by society, but the elderly are often seen as a social and economic burden (Cinar et al., 2018).

Lack of students' knowledge of the ageing process may not affect attitudes toward older people however poor knowledge of gerontic care may result in potentially placing elderly patients at risk. (Alamri \& Xiao 2017). So the present study aimed to evaluate the student's knowledge and attitudes related to the physiological changes of the elderly people at ElAzhar University.

Regarding socio-demographic characteristics of the studied students: The present study revealed that, about half of the studied students aged $>20$ years old with mean age \pm SD $20.48 \pm 1.32$. This the suitable ages for university students.

Regarding faculty, it was observed that half of studies students were from faculty of education and, while other half were from the faculty of Sharia and low. This was important to ensure the comparability of the studied sample, and indicate successful randomization.
Regarding the students' academic year, it was found that more than one-third of the studied groups were in the second and the third year and majority of them were single. These findings are matching with Abdallah \& Gabr, (2014) who found in the study entitled "Depression, anxiety and stress among first year medical students in an Egyptian public university" the majority of university students were single their ages more than 20 years old.

Regarding the number of the family member, it was found one-third of studies sample have six to seven and, more than half of them live in urban and did have an elderly person with age sixty to sixty nine years. This result agreed with Chróinín, \& Coulter, (2012) which found in the study entitled "The impact of initial teacher education on understandings of physical education: Asking the right question" In Europe that more than two-fifths of the population lives in urban areas. But this not match with Thabit et al., (2018) who found in the study entitled " Evaluation of knowledge about epilepsy and attitudes towards patients with epilepsy among university students" in Upper Egypt majority of studied university students were from rural areas and married.

In this respect Twagiramariya, (2018) found in the study entitled " Knowledge about ageing and attitudes towards caring for older people among undergraduate nursing students' in the Western Cape, that there was a significant difference in attitudes between students who lived with older people and students who did not live with older people $(t=2.565, p=.012)$. There was a positive relationship between attitudes and preference for working with older people $(r=.342, p=.001)$.

The study showed that total studied students' knowledge level about physiological changes of elderly people, illustrated that the majority of the studied students had fair knowledge level.

This result agreed with Mhaidat et al., (2018) who mentioned in the study entitled "Knowledge and awareness of colorectal cancer early warning signs and risk factors among university students" in Jordan, that the total students' knowledge was good related to the physiological disturbances among the elderly persons.

This result disagreed with Endsley, (2017) in the other hand found in the study entitled "Direct measurement of situation awareness" the level of student awareness and knowledge about the main changes of the old ages was poor and not aware about these changes.

Regarding the relationship between studied students' knowledge level about physiological changes of elderly people and their personal data, the present 
study illustrated that there was no statistically significant relationship except their faculty type with $\left(\mathrm{p}\right.$-value $\left.=0.014^{*}\right)$. The study also showed that the fourth and fifth academic year, more than twenty years old, married, with more than seven family number from the urban area and who had an elderly person at home were the majority of the studied students who had a good knowledge level.

Most of the previous studies indicated that senior students had a higher level of knowledge about ageing compared to the fresh one Jeruszka-Bielak et al., (2018) in the study entitled "Are nutrition-related knowledge and attitudes reflected in lifestyle and health among elderly people?" in the European centuries. However, this comparison was in the same line with our present study.

In the same line Sokolowska et al., (2018) found out in the study entitled "Evaluation of young adults' attitudes towards the elderly" in Turkey that there was no significant difference among class levels ( $\mathrm{p}>$ 0.05), but second year students' total knowledge scores were higher than the other class levels. This finding may be interpreted as an increase in knowledge and awareness in geriatrics for high-class level.

In this regard González-Carrasco et al., (2017) mentioned in the study entitled " Changes with age in subjective well-being through the adolescent years: Differences by gender" in Spain, that there was a relation between the students' ages and their knowledge level scores regarding the changes that occur in the old ages.

The study of Augustin \& Freshman, (2016) found in the study entitled "The effects of service-learning on college students' attitudes toward older adults in the USA, that the developmental stage of the students did not affect on their level of awareness and attitude toward the needs and changes among older persons As regards total attitude score, our study data illustrated that the majority of the studied students had a negative attitude toward elderly people.

The negative attitudes towards the elderly had increased; the students' attitudes are not independent of societal attitudes. Thus, all society' attitudes need to be improved positively. Giving gerontological content in the school curriculum for children or on media may be an alternative way to enhance awareness of society towards the discrimination against older people.

This result not match with Zisberg et al., (2015) who found in the study entitled " Cultural-and educational-level differences in students' knowledge, attitudes, and preferences for working with older adults " in Chines, a positive attitudes among the students added that this may be as a result of social and cultural perspectives of the Arab population. While, Zhang et al., (2016) study entitled " Attitudes toward older adults: A matter of cultural values or personal values?" in from the sixth wave of World Values Survey, mentioned that the multicultural society holds similar values, cultural and religious norms towards older adults.

Students' attitudes were affected by cultural values and experience of dealing with older in another similar study Benomir et al., (2016) in the study entitled " Attitudes towards people with intellectual disability" in the UK and Libya. The oriental traditional customs of respecting older adults are practiced since childhood in many societies. Compared to Egyptian, extended family systems are also predominantly practiced in Arabian societies such as Chinese and Indians.

In this respect, the results of Söylemez et al., (2018) study showed in the study entitled " Examining Nursing Students' Attitudes Towards the Elderly and Factors Affecting Attitudes Towards the Elderly" in Turkey, that overall students had slightly positive attitudes towards the elderly based on total mean attitude score. Another study on attitudes of Turkish medical and nursing students found a score quite close to our result Darling et al., (2018) found the similar attitude findings towards the elderly in the study entitled " Undergraduate nursing students and the elderly: An assessment of attitudes" in a Turkish university, that were obtained from different cultures can be explained as one of the effects of economic, social and cultural changes such as nations becoming closer together and similarity of cultural life that occurred during globalization.

The present study illustrated that; there was no statistically significant relationship between studied students' attitude level toward elderly people and their socio-demographic data. This result in line with North, \& Fiske, (2015) who found in the study entitled " Modern attitudes toward older adults in the aging world: A cross-cultural meta-analysis" in North American, that total attitude scores $(\mathrm{r}=-0.14, \mathrm{p}=$ $0.003)$ as well as the total negative item scores $(\mathrm{r}=-$ $0.11, \mathrm{p}=0.024$ ) were negatively and significantly correlated with their ages. Although the strength of the correlation coefficients was low, they were significant - meaning that as students get older, their attitude scores tend to become worse. In contrast, there was no correlation between students' attitudes and age groups in a study conducted in Ucun et al., (2015) study entitled "Youth attitudes toward elderly people" in Turkey.

No statistically significant difference was found between the attitude scores of the students who participated in the study according to their year of 
study. Different from our study, it was found in some other studies that as students' age and education level increased their positive discrimination toward elderly also increased (Buz, 2015). This is explained by Domeyer et al., (2018) in the study entitled "Greek students' attitudes, perception and knowledge regarding generic medicines in times of economic crisis: a cross-sectional study" in Greek, who concluded that understanding of old age with the maturity of individuals with increasing age.

It was found in our study that the total attitude scores and the mean scores for negative attitude toward elderly of students who stated that they lived in the same house as an old person were significantly higher than those who did not live in the same house as an old person.

Overall, researchers have suggested various factors that can affect attitudes towards older people such as age, gender, culture, education, personality traits, clinical experience and experience with the elderly Shankar et al., (2016) in the study entitled "Assessment of knowledge and perceptions toward generic medicines among basic science undergraduate medical students at Aruba" in India. Our study indicated that students at the age of 20 or over and living in the city had more positive attitudes. In the literature, there are conflicting results. Some studies pointed out that older health care professionals and students had more positive attitudes Jamshed et al., (2015) in the study entitled "Understanding and perceptions of final-year doctor of pharmacy students about generic medicines" in Karachi, Pakistan.

However, Lee et al., (2016) reported in the study entitled "Sexual health and well-being among older men and women" in England, no significant correlation between age and attitudes towards older people. As a second factor affecting attitude, we found that students who were living in the city had more positive attitudes. Conversely, no differences in attitudes were reported between those living in towns/villages or the city in a study by Köse et al., (2015).

Additionally, our study showed that there wasn't a statistically significant difference between family characteristics (number of its members) and attitudes of the students. Similar findings were observed in the studies by Arun \& Pamuk, (2014).

In the other hand, Sheikh et al., (2013) in the study entitled "Attitude of medical students toward old people" in Ajman, United Arab Emirates suggested that second year students who have more positive attitudes than senior students. However, previous studies observed that students have more positive attitudes when class level increases (Uysal et al., 2014).

It has been found that young people display a more negative attitude toward old age than other age groups Dimitriadou- Panteka et al., (2014) in the study entitled " The Concept of Self-Esteem in Nursing Education and its Impact on Professional Behavior." included EU and WHO official publications. In the present study, the attitudes of university students studying in different fields toward the elderly were examined, and it was found that they generally had a negative attitude.

The results of various studies carried out with university students have yielded higher attitude scores than in the present study and a positive attitude toward elderly Saruhan et al., (2013) in the study entitled " Adnan Menderes University Elder Care Technician Program: Students' Expectations for Trade Branch." in Turkey.

Regarding the correlation between knowledge and attitude: The present study showed that there was a significant positive correlation between knowledge score and attitude score $(r=0.114 \& \mathrm{p}=0.029)$ regarding elderly persons. This indicates that students with higher knowledge about ageing may possess more positive attitudes towards older adults or vice versa. This finding is consistent with results from previous studies, Turan et al., (2016) in the study entitled "Attitudes of students of health sciences towards the older persons" in Turkey.

This finding disagreed with Wilson et al., (2016) who confirmed in the study entitled "Knowledge of palliative care and attitudes towards nursing the dying patient" in the UK, that the knowledge of aging itself had no significant effect on the level of attitudes. In addition, they suggested that, in attempting to develop programs to reduce ageist attitudes, the key variables may be through enhancing the knowledge of the young toward older care.

\section{Conclusion}

The majority of El-Azhar university students had a fair score of knowledge related to physiological changes which occur to the elderly people and the majority of them had a negative attitude toward elderly people. In addition, there was a significant positive correlation between knowledge score and attitude score $(r=0.114 \& \mathrm{p}=0.029)$ regarding elderly persons.

\section{Recommendation}

1- More researches should be done to further investigate and determine the factors influencing students' attitudes toward the care of older adults. 
2- Effective use of mass media and social media in order to raise awareness and to change negative attitudes and stereotypes toward ageing.

3- Increase the number of books in the different libraries regarding the aged and ageing process.

\section{Reverences}

1. Abdallah, A., \& Gabr, H., (2014): Depression, anxiety and stress among first year medical students in an Egyptian public university. Int Res J Med Med Sci, 2(1), 11-19

2. Augustin, F., \& Freshman, B., (2016): The effects of service-learning on college students' attitudes toward older adults. Gerontology \& geriatrics education, 37(2), 123-144.

3. Alamri, B., \& Xiao, L., (2017): Health professionals' knowledge and attitudes toward older people in primary care in Saudi Arabia. Saudi medical journal, 38(3), 229.

4. Arun Ö., \& Pamuk D., (2014): Ageism in Institutional Care, Causes of the Discriminatory Attitudes of Older Care Staffs towards Ageing and Old Age and Intervention Strategies. Med J Humanities; IV/2:19-33.

5. -Aubrey, D., \& Grey D., (2017): life spans extension, research and public debate: societal consideration. Studies in ethics, low, and technology I. available: http://www.mfoundation.org.

6. -Benomir, A., Nicolson, R., \& Beail, N., (2016): Attitudes towards people with intellectual disability in the UK and Libya: A cross-cultural comparison. Research in developmental disabilities, 51, 1-9.

7. Brandfonbrener M., Landomwne M., \& Shock N., (2018): changes in cardic function with age. Circulation 12:567-567, lakatta EG Age- related alteration in the cardiovascular response to adrenergic mediated stress fed proc 39:0015-0019.

8. Buz S., (2015): Age discrimination for elderly persons. Electronic J Soc Sci 2015;14:268-78.

9. Central agency for public mobilization statistic, (2019): in Egypt. Available at:http://www.un.org/en/section/issuesdepth/aging. -

a. Central Agency for Public Mobilization and Statistics, (2017): in Egypt. Available at:http://www.un.org/en/section/issuesdepth/aging.

b. Cabeza R., Moscovitch, (2019): Memory systems, processing modes, and components: functional neuroimaging evidence. Perspectives on psychological science.;8(1):49-55.
10. Chróinín, D., \& Coulter, M., (2012): The impact of initial teacher education on understandings of physical education: Asking the right question. European Physical Education Review, 18(2), 220-238.

11. -Cinar, D., Karadakovan, A., \& Sivrikaya, S., (2018): Investigation of the attitudes of university students to discrimination of the elderly. Northern clinics of Istanbul, 5(1), 2.

12. Dimitriadou, Panteka, A., Koukourikos, K., \& Pizirtzidou, E., (2014): The Concept of SelfEsteem in Nursing Education and its Impact on Professional

Behavior. International Journal of Caring Sciences, 7(1), 6-11.

13. Dobriansky P., Suzman R., \& Hodes R., (2015): Why Population Aging Matters: A Global Perspective. National Institute on Aging, National Institutes of Health, US Department of Health and Human Services, US Department of State.

14. Domeyer, P., Katsari, V., Sarafis, P., Aletras, V., \& Niakas, D., (2018): Greek students' attitudes, perception and knowledge regarding generic medicines in times of economic crisis: a cross-sectional study. BMC medical education, 18(1), 262.

15. Darling, R., Sendir, M., Atav, S., \& Buyukyilmaz, F., (2018): Undergraduate nursing students and the elderly: An assessment of attitudes in a Turkish university. Gerontology \& geriatrics education, 39(3), 283-294.

16. Endsley, M., (2017): Direct measurement of situation awareness: Validity and use of SAGAT. In Situational Awareness (pp. 129156). Routledge.

17. González-Carrasco, M., Casas, F., Malo, S., Viñas, F., \& Dinisman, T., (2017): Changes with age in subjective well-being through the adolescent years: Differences by gender. Journal of Happiness studies, 18(1), 63-88.

18. Hope K., (2016). Nursing attitude towards older people: acomparison between nurses warking in a cure medical and advanced nursing; 20: 605612 .

19. Jamshed, S., Ibrahim, M., Hassali, M., Sharrad, A., Shafie, A., \& Babar, Z., (2015): Understanding and perceptions of final-year Doctor of Pharmacy students about generic medicines in Karachi, Pakistan: a quantitative insight. Advances in medical education and practice, 6, 359 .

20. Jeruszka-Bielak, M., Kollajtis-Dolowy, A., Santoro, A., Ostan, R., Berendsen, A., Jennings, A., \& de Groot, L., (2018): Are 
nutrition-related knowledge and attitudes reflected in lifestyle and health among elderly people? A study across five European countries. Frontiers in physiology, 9 (22), 98.

21. Knight Y., \& Nigam M., (2018): The anatomy and physiology of ageing. Part 1the cardiovascular system," Nursing Times, vol. 104, no. 31, pp. 26-27.

22. Köse G., Ayhan H., Taştan S., İyigün E., Hatipoğlu S., \& Açıkel C., (2015): Determining the attitudes of the students who study in different sectors to the elderial discrimination in the feld of health. Gülhane Med J 2015;57:145-51.

23. Lee, D., Nazroo, J., O'Connor, D., Blake, M., \& Pendleton, N., (2016): Sexual health and well-being among older men and women in England: Findings from the English Longitudinal Study of Ageing. Archives of Sexual Behavior, 45(1), 133-144.

24. McNicoll G., (2018): Consequences of rapid population growth: An overview and assessment.

25. Mhaidat, N., Al-husein, B., Alzoubi, K., Hatamleh, D.., Khader, Y., Matalqah, S., \& Albsoul, A., (2018): Knowledge and awareness of colorectal cancer early warning signs and risk factors among university students in Jordan. Journal of Cancer Education, 33(2), 448-456.

26. National Institute on Aging, (2019): Age Page: Taking Care of Your Teeth and Mouth retrieved from http://www.niapublications.org/agepages/teeth.a $\mathrm{sp}$.

27. North, M., \& Fiske, S., (2015): Modern attitudes toward older adults in the aging world: A cross-cultural meta-analysis. Psychological bulletin, 141(5), 993.

28. Purty A., Bazroy J., Kar M., Vasudevan K., Veliath A., \& Panda P., (2018): Morbidity Pattern among the elderly population in the rural area of Tamil Nadu, India.Turk $\mathbf{J}$ Med Sci;36:45-50.

29. Palmore, E., (2000): the fact on aging quiz: part two the gerontologeist, 2: 431-437.

30. Saruhan, G., Evci Kiraz, E., Ergin, F., Beşer, E., \& Başaloğlu, H., (2013): Adnan Menderes University Elder Care Technician Program: Students'

Expectations for Trade Branch. Journal of Adnan Menderes University Medical Faculty, 14(2), 19-23.
31. Shankar, P., Herz, B., Dubey, A., \& Hassali, M., (2016): Assessment of knowledge and perceptions toward generic medicines among basic science undergraduate medical students at Aruba. Indian journal of pharmacology, 48(Suppl 1), S29.

32. Sheikh R., Mathew E., Rafquel A., Suraweera R., Khan H., Sreedharan J., (2013): Attitude of medical students toward old people in Ajman, United Arab Emirates. Asian Journal of Gerontology and Geriatrics 2013;8:85-9.

33. Sieck L., (2018): Physiology of aging," Journal of Applied Physiology, vol. 95, no. 4, pp. 13331334.

34. Sokołowska, N., Kasperska, P., Sokołowski, R., Mazur, E., Podhorecka, M., Stemplowski, W., \& Kędziora, Kornatowska, K., (2018): Evaluation of young adults' attitudes towards the elderly Ocena postaw młodych dorosłych wobec osób w podeszłym wieku. gerontologia polska, 4

35. Söylemez, B., Küçükgüçlü, Ö., Tekin, D., Ergin, S., \& Yaman, A., (2018): Examining Nursing Students' Attitudes Towards the Elderly and Factors Affecting Attitudes Towards the Elderly. Dokuz Eylül Üniversitesi Hemşirelik Fakültesi Elektronik Dergisi, 11(2).

36. Turan, E., Yanardag, M., \& Metintas, S., (2016): Attitudes of students of health sciences towards the older persons. Nurse education today, 36, 53-57.

37. Thabit, M., Sayed, M., \& Ali, M., (2018): Evaluation of knowledge about epilepsy and attitudes towards patients with epilepsy among university students in Upper Egypt. Epilepsy research, 144, 30-33.

38. Twagiramariya, B., (2018): Knowledge about ageing and attitudes towards caring for older people among undergraduate nursing students in the Western Cape, P.P. 47-55

39. Uysal G., Beydağ D., Sensoy F., Özaydin N., \& Kiyak M., (2014): Attitudes of students who receive health education in a foundation university regarding age discrimination. Procedia Soc Behav Sci 2014;152:430-34.

40. Ucun Y., Mersin S., Öksüz E., (2015): Youth attitudes toward elderly people. IntJ Soc Res Methodol 2015;8:1143-49.

41. Worled Health Organization (2018): Aging , Available http://www.un.org/en/section/issuesdepth/aging.

42. World Health Organization, (2019): The world report on ageing and health. Available 
at:http://www.un.org/en/section/issues-

depth/aging.

43. Wilson, O., Avalos, G., \& Dowling, M., (2016): Knowledge of palliative care and attitudes towards nursing the dying patient. British Journal of Nursing, 25(11), 600605

44. Zhang, X., Xing, C., Guan, Y., Song, X., Melloy, R., Wang, F., \& Jin, X. (2016): Attitudes toward older adults: A matter of cultural values or personal values?. Psychology and aging, 31(1), 89.

45. Zakari, N., (2005): Attitudes towards the elderly and knowledge of aging as correlates to the willingness and intention to work with elderly among Saudia nursing students .PH.D. Dissertation, George Mason University.

46. Zisberg, A., Topaz, M., \& BandWintershtein, T., (2015): Cultural-and educational-level differences in students knowledge, attitudes, and preferences for working with older adults: an Israeli perspective. Journal of Transcultural Nursing, 26(2), 193-201. 